\title{
Argumentação retórica: aspectos teóricos e práticos
}

\author{
Antônio Lailton Moraes Duarte* \\ Edmar Peixoto de Lima** \\ Rosalice Botelho Wakim Souza Pinto ${ }^{* * *}$
}

\begin{abstract}
Resumo: O objetivo deste trabalho é investigar de que forma as técnicas argumentativas podem ser utilizadas em um discurso jurídico para convencer um auditório a determinada tese. Elegemos, como documento de análise, o texto que registra o voto do Ministro-Relator Carlos Ayres Britto relativo à ação de descumprimento de preceito fundamental (ADPF) $n^{\circ}$. 132/RJ e à ação direta de inconstitucionalidade (ADI) $n^{\circ}$. 4277/DF. Baseamo-nos em pressupostos teóricos de Perelman e Olbrechts-Tyteca (2005) e Amossy (2017, 2018). Resultados preliminares demonstram que o orador constrói uma diversidade de ethè, em função de um auditório específico (pathos institucionalmente assente).
\end{abstract}

Palavras-chave: Argumentação. Retórica. Técnicas Argumentativas.

\begin{abstract}
The aim of this paper is to investigate how argumentative techniques can be used in a legal discourse in order to convince an audience to a particular thesis. We elected, as an analysis document, the text that registers the vote of the Minister-Rapporteur Carlos Ayres Britto regarding the breach of fundamental precept (ADPF) no. 132 / RJ and the Direct Unconstitutionality Action (ADI) $n^{\circ} .4277$ / DF. Our study is based on Perelman and OlbrechtsTyteca (2005) and Amossy (2017, 2018) theoretical approaches. Preliminary results demonstrate that the speaker builds a diversity of ethè, according to a specific audience (pathos institutionally constructed).
\end{abstract}

Key-words: Argumentation. Rhetoric. Argumentative Techniques.

Résumé: Le but de cet article est d'étudier comment les techniques argumentatives peuvent être utilisées dans un discours juridique pour convaincre un public à une thèse particulière. Nous avons élu, en tant que document d'analyse, le texte qui correspond au vote du ministrerapporteur Carlos Ayres Britto concernant la violation d'un précepte fondamental (ADPF) $\mathrm{n}^{\circ}$.

\footnotetext{
* 1 Doutorando em Linguística pela Universidade Federal do Ceará (UFC/CNPq) e membro do grupo de pesquisa Protexto (CNPq/UFC). http://orcid.org/000o-0003-4099-4858

** 2 Doutorado em Linguística Aplicada pela Universidade Estadual do Ceará (UECE) e membro do grupo de pesquisa Protexto (CNPq/UFC). http://orcid.org/oooo-0001-8827-1136

${ }^{* * *} 3$ Pós-doutorada em Ciências da Comunicação pela Universidade de Genebra e Universidade Nova de Lisboa (2013) e membro do grupo de pesquisa Protexto (CNPq/UFC). http://orcid.org/000o-0002-7638-654X
}

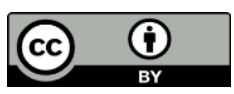

Este artigo está licenciado sob forma de uma licença Creative Commons Atribuição 4.0 Internacional, que permite uso irrestrito, distribuição e reprodução em qualquer meio, desde que a publicação original seja corretamente citada. 
132 / RJ et d'une Exception d'Inconstitutionnalité (ADI) n ${ }^{\circ} .4277$ / DF. Nous nous basons sur les approches théoriques de Perelman et Olbrechts-Tyteca (2005) et Amossy (2017, 2018). Les résultats préliminaires démontrent que le locuteur construit une pluralité d'ethè, selon un public spécifique (pathos institutionnellement construit).

Mots-clés: Argumentation. Rhétorique. Techniques Argumentatives.

\section{Introdução}

É de conhecimento de todos que, desde a Antiguidade, a partir de Aristóteles, são muitos os teóricos que, segundo perspectivas distintas, vêm se debruçando sobre o estudo da argumentação.

Na contemporaneidade, em especial, a argumentação, no período pós - $2^{\text {a }}$ Guerra Mundial, começou a ressurgir de forma mais contundente, com o objetivo de dirimir as divergências a nível mundial. É neste contexto que surgem os trabalhos no âmbito da Nova Retórica de Perelman e Olbrechts-Tyteca (2005), na busca de uma argumentação ligada diretamente à retórica, a favor de uma dimensão ética e social do discurso. Com isso, esses autores preconizam a existência de uma taxinomia de técnicas argumentativas que poderia ser utilizada por um orador para atingir o objetivo pretendido junto a um auditório, de forma a que este venha a aderir à tese pretendida.

Ou, ainda, devem ser destacadas as contribuições de Amossy (2017, 2018) centradas no estudo da argumentação do ponto de vista discursivo. Na verdade, esta é construída através de escolhas linguísticas (contextualmente situadas) perpetradas por um agente para atender determinada visada argumentativa, embora a dimensão argumentativa esteja sempre intrinsecamente ligada à construção discursiva.

Evidentemente, muitos outros estudos ainda poderiam ser citados, como os de Anscombre \& Ducrot (1988) sobre a argumentação na língua, restringindo a argumentação ao nível do enunciado; os de Plantin (1990), estudando a argumentação presente nas interações verbais; os de Pinto (2010) relativo à argumentação em gêneros textuais. 
Contudo, este trabalho centrar-se-á, fundamentalmente, nos pressupostos teóricos da Nova Retórica para o levantamento de técnicas de argumentação presentes em textos de natureza jurídica: o voto do Ministro-Relator Carlos Ayres Britto relativo à ação de descumprimento de preceito fundamental (ADPF) $n^{\circ}$. 132/RJ e à ação direta de inconstitucionalidade (ADI) $\mathrm{n}^{\circ} \cdot 4277 / \mathrm{DF}$.

De forma a atender o objetivo pretendido, faremos primeiramente uma exposição teórica dos elementos que serão convocados para as análises; em seguida, mostraremos aspectos genéricos relevantes sobre o voto de um Ministro do Supremo Tribunal Federal, uma vez que consideramos que o estudo das técnicas argumentativas deve ser contextualmente situado. Passaremos, por fim, à análise propriamente dita e a algumas considerações finais.

\section{Pessupostos teóricos}

Concebemos a argumentação como uma área de estudos, estando filiada a diversas vertentes teóricas com diferentes perspectivas de análise. No nosso caso específico, centramo-nos no que denominamos argumentação retórica. Esta é assim denominada por apresentar em sua base de pesquisa tanto uma veiculação aos estudos aristotélicos, quanto aos estudos discursivos. Portanto, é este o posicionamento que guiará o nosso percurso de trabalho.

Sobre a retórica, ela foi/é de fundamental importância para os estudos da argumentação na contemporaneidade. Nas palavras de Pinto (2010, p. 33) "a herança aristotélica" e as noções de ethos, pathos e logos, dentre outras, advindas deste período contribuíram significativamente para o desenvolvimento das teorias da argumentação.

Quanto à vertente discursiva, a análise argumentativa constitui um ramo da própria análise do discurso (AD), uma vez que esta última se preocupa em analisar o funcionamento discursivo da linguagem situada e contextualmente coibida, como aponta Amossy (2017, 2018). 
Face a este posicionamento, assumimos aqui as palavras de Perelman e Olbrechts-Tyteca (2005) quando defendem que, na argumentação, cabe ao orador provocar no auditório, a quem os discursos são direcionados, um tipo de reação. E será o orador, em função da imagem que quer transmitir ao auditório ao qual se dirige, que selecionará as técnicas argumentativas mais adequadas em determinada situação. Neste trabalho, em especial, observaremos a argumentação retórica e os modos de argumentar assentes num discurso específico: o jurídico.

Assim, a noção de orador está vinculada à ideia de um falante que se apropria dos discursos para se posicionar com relação às crenças e às convicções que acredita e defende, mantendo com o seu auditório uma relação dialógica. Sob essa perspectiva, cabe ao orador tentar se adequar às teses que possam ser admitidas por seu interlocutor, conforme os preceitos da Nova Retórica, defendidos em Perelman e Olbrechts-Tyteca (2005). Em suma, o orador objetiva influenciar o auditório e para isso, defende seus posicionamentos e imprime, nestes, valores ideológicos em que acredita.

Aludimos ainda ao conceito de auditório, de acordo com Perelman e OlbrechtsTyteca (2005). Estes afirmam ser a audiência o objetivo de toda a argumentação. Nesse sentido, para os estudiosos, o auditório corresponde "ao conjunto daqueles que o orador quer influenciar" (PERELMAN; OLBRECHTS-TYTECA, 2005, p. 22). Assim sendo, o orador se apropria de diversos modos de argumentar, sendo as técnicas argumentativas uma dessas formas.

Para Perelman e Olbrechts-Tyteca (2005), as técnicas se subdividem em dois tipos: as de ligação e as de dissociação. Neste artigo, apresentamos apenas aquelas que foram identificadas nos documentos de análise. Por essa razão, trataremos das técnicas argumentativas de ligação, primeiramente, com os argumentos quase-lógicos, priorizando os argumentos por contradição, por comparação e a regra de justiça.

As técnicas argumentativas de ligação, denominadas de argumentos quaselógicos "são os que lembram a estrutura de um raciocínio lógico, mas suas conclusões não são logicamente necessárias" (FIORIN, 2015, p. 116). O argumento por contradição, pertencente aos quase-lógicos, possibilita ao orador apresentar e perceber se a ideia defendida é plausível e/ou aceitável, embora não apresente necessariamente "um ponto 
de vista lógico" (FIORIN, 2015, p. 116). Já o argumento por comparação permite ao orador estabelecer relações de aproximação entre dois objetos, expondo os atributos ou as qualidades de um em comparação ao outro. Normalmente, esta relação parte do elemento mais conhecido pelo auditório. Com relação à regra de justiça, a ideia é a de que todo cidadão seja igual perante a lei. O que vale para um vale para todos. Essa técnica se baseia na compreensão de que mesmo os seres humanos pertencentes a contextos situacionais diferentes devam ser tratados igualmente.

Já os argumentos baseados na estrutura do real se configuram diferentes dos anteriores, pelo fato de manterem as significações mais ligadas à realidade social. Em outras palavras, referem-se aos acontecimentos existentes que fazem parte do conhecimento do interlocutor. O orador recorre a esses argumentos com o objetivo de ressaltar as situações que pertençam ao mundo de significados do auditório. Neste artigo, esta técnica argumentativa se manifesta pela presença do argumento pragmático e do argumento de autoridade. Para Perelman e Olbrechts-Tyteca (2005, p. 303), o argumento pragmático refere-se à ideia de um "ato ou um acontecimento consoante suas consequências favoráveis ou desfavoráveis". Nesse argumento, para que algo seja apreciado pelos interlocutores como estratégia argumentativa, convém que primeiro se analisem os impactos provocados por ele para só depois apreciá-lo. Já com relação ao argumento de autoridade, é uma técnica que consiste em permitir que o orador recorra à figura de maior prestígio na sociedade como forma de influenciar o auditório. Nas palavras de Perelman e Olbrechts-Tyteca, (2005, p. 348) o argumento de autoridade se utiliza de "atos ou juízos de uma pessoa ou de um grupo de pessoas como meio de prova a favor de uma tese".

No tocante aos argumentos que fundamentam a estrutura do real, trataremos apenas do uso da metáfora que se configura como um elemento de argumentação importante na construção de significados dos discursos. É por meio dos recursos metafóricos que o orador pode recorrer ao uso de expressões que provoquem no auditório a possibilidade de estabelecer relações de proximidade entre o que ele (auditório) experienciou e as ideias defendidas pelo orador. O uso da metáfora, a nosso ver, se configura como uma forma particular e individualizada de observar as coisas e, 
consequentemente, poderá suscitar no auditório a construção de significações que possibilitem a aceitação das teses defendidas pelo orador.

De acordo com as nossas discussões sobre algumas técnicas argumentativas, foi possível perceber que elas podem funcionar como estratégias que são acionadas pelo orador na tentativa de conseguir a adesão do auditório às teses defendidas. Convém ainda salientar que apresentamos apenas as técnicas que foram identificadas nos documentos de estudo e que, embora essas tenham sido analisadas separadamente, elas se inter-relacionam na construção do(s) discurso(s).

Na seção seguinte, caracterizaremos de forma genérica o voto de um ministro relator do Supremo Tribunal Federal.

\section{Caracterização genérica do voto de um ministro relator do Supremo Tribunal Federal}

É consensual que "[...] o tom, o estilo, e mesmo a forma de autoria, entre outros fatores são determinados pelo gênero [...]" (PISTORI, 2018, p. 79), aqui o Voto do Ministro-Relator no STF. Em uma demanda judicial, o Voto é definido como sendo "a opinião manifestada a respeito de determinado fato [...] Pelo voto, a pessoa dá o seu parecer, manifesta sua opinião [...]" (SILVA, 1997, p. 508).

No caso deste Voto, temos um voto consultivo, tendo em vista que ele não tem poder decisório, mas orientador - não determinativo - da decisão que o colegiado de Ministros da Suprema Corte deve tomar, e é parte do ritual procedimental daquela corte. Dessa forma, o Ministro-Relator é o responsável pelo aprofundamento detalhado dos estudos sobre o tema objeto da demanda judicial, por uma compreensão mais ampla da questão a ser decidida, tendo em vista que, ao exercer a função orientadora, tal como um parecer, no Voto, o Ministro-Relator é o primeiro membro da Corte Superior a manifestar sua opinião e sua justificativa, no intuito de orientar os votos dos outros membros da Corte e de expressar novamente a polêmica social no 
posicionamento axiológico assumido por ele, constituindo-se, a nosso ver, em um discurso polêmico, caracterizado, no nosso entendimento, pela modalidade polêmica (AMOSSY, 2017).

No entanto, cremos que a manifestação da opinião e da justificativa presente no Voto do Ministro-Relator vai além de uma mera função orientadora, pois esta está imbuída de uma função argumentativo-persuasiva, que tenta influenciar, de acordo com Macedo (2018), pelos recursos da linguagem, os modos de ver, de pensar e de sentir dos outros Ministros da Corte diante da questão polêmica que atravessa a demanda judicial em questão. E, na apresentação das razões opostas, a busca é, de preferência, pelo consenso, entretanto como nem sempre isso ocorre - tanto no STF como na sociedade democrática pluralista brasileira, pode ocorrer o dissenso (AMOSSY, 2017), em que as questões polêmicas atravessam as interações sociais humanas (MACEDO, 2018), na medida em que, de acordo com Pistori (2018, p. 79), “[...] há uma decisão, mas sempre poderá ser discutida.”, inclusive um Ministro pode abrir divergência durante o julgamento e travar uma polêmica sobre determinado tema para prevalecer o seu entendimento em detrimento do Ministro-Relator, por exemplo.

O Voto do Ministro Carlos Ayres Britto, Relator das ações do controle concentrado de constitucionalidade, compõe-se de um longo texto com 37 parágrafos, 49 páginas no original. Este Voto é composto de duas partes: o relatório, em que é feita uma síntese da questão jurídica, e o Voto propriamente dito, em que o Ministro apresenta o seu entendimento sobre a questão. Deter-nos-emos especialmente na segunda parte, o Voto propriamente dito, mas nos referiremos à primeira parte, o Relatório, para atingir os objetivos propostos desta investigação, quando for necessário.

Na subseção seguinte, discutiremos os modos de argumentar, observando como o orador se apropria dos elementos argumentativos abordados neste trabalho com a finalidade de influenciar o auditório a quem os discursos se direcionam.

\section{Análise dos dados e discussão dos resultados}


Fundamentados nos pressupostos de Perelman e Olbrechts-Tyteca (2005) referentes às técnicas argumentativas, apresentamos as análises dos argumentos utilizados pelo Ministro-Relator (Carlos Ayres Britto) no seu voto proferido durante o julgamento da ADI no 4.277/RJ e ADPF no 132/RJ, conforme já mencionado. Procuraremos mostrar como as escolhas linguísticas perpetradas pelo ministro-relator, no caso, expressam uma avaliação/posicionamento ideológico em relação ao conteúdo e como a avaliação ideológica se realiza tecnicamente em relação ao material (VOLOCHINOV, apud TODOROV, 1981). Dessa forma, a construção discursiva do reconhecimento da união homoafetiva como entidade familiar no caso em tela, por parte do Ministro Relator, é demonstrada através do tom apreciativo presente em cada enunciado de forma a obter a adesão do auditório à tese por ele defendida. Com isso, a argumentação não se restringe à "forma composicional" propriamente dita, mas vai além, uma vez que esses enunciados são atrelados a diversas técnicas argumentativas criteriosamente selecionadas pelo produtor do texto (o próprio relator).

Antes de passarmos às análises propriamente ditas, algumas observações prévias devem ser feitas até para justificar algumas limitações do nosso estudo.

Inicialmente, esclarecemos que, embora tenha sido observado, ao longo das 49 páginas do voto em questão, o uso de diferentes técnicas argumentativas pelo relator das referidas ações analisadas, optamos pela análise de alguns argumentos em função de sua significativa incidência. Dessa forma, centramo-nos no estudo de alguns deles: os quase-lógicos, os baseados na estrutura do real e os que que fundam a estrutura do real. Para os primeiros, mostraremos os por contradição, por comparação e regra de justiça; para os segundos, os pragmáticos (de sucessão) e os de autoridade (coexistência) e para os demais centrar-nos-emos na metáfora, por percebemos que estes argumentos revelam o tom apreciativo presente em cada enunciado no processo de construção do ponto de vista do Ministro-Relator em relação aos seus interlocutores para influenciálos a seguirem o seu voto.

Além desse esclarecimento inicial, salientamos, como apontam Perelman e Olbrechts-Tyteca (2005), que os recortes apresentados na análise são parte integrante 
de um discurso maior. Lembremos que este, por sua vez, constitui toda a argumentação defendida no voto do Ministro-Relator, de forma que, como afirmam Perelman e Olbrechts-Tyteca (2005, p. 211):

[...] o sentido e o alcance de um argumento isolado não podem, senão raramente, ser compreendidos sem ambiguidade; a análise de um elo da argumentação, fora do contexto e independentemente da situação em que ele se insere, apresenta inegáveis perigos.

Assumimos assim, que, ao fazer o recorte do voto do Ministro para análise, por limitações espaciais no corpo deste trabalho, corremos este risco. Além disso, as possibilidades de interpretação de um mesmo argumento são, a nosso ver, infinitas, pois, como bem salientam os autores, “[...] um mesmo argumento pode ser compreendido e analisado diferentemente por diferentes ouvintes e que as estruturas lógicas podem ser consideradas matemáticas e inversamente". (PERELMAN e OLBRECHTS-TYTECA, 2005, p. 221).

Feitas essas ponderações, apresentamos, a seguir, as análises que revelam o uso dos argumentos no voto do Ministro-Relator no julgamento das ações do controle de constitucionalidade em questão, de modo a mostrarmos como as formas revelam a avaliação ideológica, em relação ao conteúdo, e a realizam, tecnicamente, em relação ao material.

\subsection{Argumentos quase-lógicos}

Os argumentos quase-lógicos são aqueles amparados por princípios lógicos, pois “[...] se apresentam como comparáveis a raciocínios formais, lógicos ou matemáticos” (PERELMAN e OLBRECHTS-TYTECA, 2005, p. 220) e obedecem à regras lógicas. Nesses argumentos se discutem contradições, incompatibilidades, regras de justiça, entre outros. No entanto, ao contrário dos princípios lógicos da demonstração, os argumentos quase-lógicos podem ser rejeitados, o que comprova que eles não são puramente lógicos. 
Dentre os argumentos quase-lógicos, analisaremos os argumentos por contradição e por comparação e, em certa medida, o de regras de justiça.

\section{Argumento por contradição}

O Ministro-Relator, a fim de garantir a adesão do auditório, faz uso de um raciocínio, respeitando os ditames previstos na Constituição Federal do Brasil (CFB) de 1988, salientando não ser possível que as pessoas nem o próprio Estado intentem tratamento discriminatório ou desigualitário sem causa justificativa. Tal fato estaria colidindo com o objetivo constitucional de promover o bem de todos, como se depreende do excerto (1) a seguir.

(1)

12. Prossigo para ajuizar que esse primeiro trato normativo da matéria já antecipa que o sexo das pessoas, salvo expressa disposição constitucional em contrário, não se presta como fator de desigualação jurídica. É como dizer: o que se tem no dispositivo constitucional aqui reproduzido em nota de rodapé (inciso IV do art $3^{\circ}$ ) é a explícita vedação de tratamento discriminatório ou preconceituoso em razão do sexo dos seres humanos. Tratamento discriminatório ou desigualitário sem causa que, se intentado pelo comum das pessoas ou pelo próprio Estado, passa a colidir frontalmente com o objetivo constitucional de "promover o bem de todos" (este o explícito objetivo que se lê no inciso em foco). (grifos do Ministro-Relator)'.

O excerto (1) configura-se como argumento quase-lógico por contradição, uma vez que o Ministro-Relator mostra que o tratamento discriminatório em razão do sexo é incompatível com a CRB de 1988. Inclusive o próprio inciso IV do art $3^{\underline{0}}$ da mesma determina que "Constituem objetivos fundamentais da República Federativa do Brasil: [...] IV - promover o bem de todos, sem preconceitos de origem, raça, sexo, cor, idade $e$

\footnotetext{
${ }^{1}$ Os numerais (1), (2), (3) ... correspondem a ordem numérica dos trechos retirado do Voto do MinistroRelator do STF proferido durante a seção do julgamento da ADPF no. 132/RJ e da ADI no. 4.277/DF, estabelecida aleatoriamente. Já o número que antecede o trecho corresponde ao número do parágrafo do Voto do Ministro-Relator, que optou por numerar os parágrafos do seu voto dada a extensão. Também a redução do tamanho da fonte e destaques de negrito, itálico e sublinhado nos trechos recortados são de nossa responsabilidade, visando a melhor realçar os aspectos que analisamos, desde que não indicado como grifo do autor.
} 
quaisquer outras formas de discriminação." (grifo nosso). Assim, o uso do argumento por contradição revela a avaliação ideológica de que o bem de todos previsto como objetivo geral fundamental da República Brasileira é incompatível com o tratamento discriminatório oriundo das formas de discriminação pela opção sexual.

Essa incompatibilidade que consiste, especialmente, na retorsão, ou seja, em “retornar o argumento do adversário mostrando que na verdade esse é aplicável contra ele mesmo" (PERELMAN e OLBRECHTS-TYTECA, 2005, p. 169), é a base do argumento por contradição utilizado pelo magistrado da Corte Maior. Ao mobilizar essa técnica para fundamentar seu posicionamento, o orador revela que há um "tratamento discriminatório ou desigualitário sem causa”, sendo, por essa razão, um pensamento incompatível com o texto constitucional por "colidir frontalmente com o objetivo constitucional de promover o bem de todos", o que seria uma grande contradição em um Estado Democrático de Direito, em que o respeito às normas constitucionais é imprescindível.

\section{Argumento por comparação}

O Ministro-Relator, a fim de cotejar as uniões heteroafetivas e homoafetivas para avaliá-las uma relação à outra, faz uso de um raciocínio para revelar que nós, seres humanos, nascemos para sermos felizes, independente da orientação sexual, e que essa felicidade pode ser realizada de diferentes maneiras, seja heteroafetivamente ou homoafetivamente, conforme se extrai do excerto (2) a seguir.

(2)

21. Óbvio que, nessa altaneira posição de direito fundamental e bem de personalidade, a preferência sexual se põe como direta emanação do princípio da "dignidade da pessoa humana" (inciso III do art. $\imath^{\circ}$ da CF), e, assim, poderoso fator de afirmação e elevação pessoal. De auto-estima no mais elevado ponto da consciência. Auto-estima, de sua parte, a aplainar o mais abrangente caminho da felicidade, tal como positivamente normada desde a primeira declaração norte-americana de direitos humanos (Declaração de Direitos do Estado da Virgínia, de 16 de junho de 1776) e até hoje perpassante das declarações constitucionais do gênero. Afinal, se as pessoas de preferência heterossexual só podem se realizar ou ser felizes heterossexualmente, as de preferência homossexual seguem na mesma toada: só podem se realizar ou ser felizes homossexualmente. Ou "homoafetivamente", como hoje em dia mais e mais se fala [...] (grifo do autor). 
O trecho do excerto (2) destacado pelo Ministro-Relator em seu voto revela que “[a] argumentação não poderia ir muito longe sem recorrer a comparações, nas quais se cotejam vários objetos para avaliá-los um relação ao outro [...]" (PERELMAN e OLBRECHTS-TYTECA, 2005, p. 274), uma vez que, a noção de analogia está presente no enunciado e sucita a ideia de igualdade de direitos. Acreditamos, inclusive, que o argumento por comparação pode vir a ser considerado a base da construção argumentativa dos textos.

Uma das provas da afirmação acima é o próprio excerto (2). Neste, o MinistroRelator usou os pesos e as medidas das uniões heteroafetivas e homoafetivas, não a partir de uma pesagem efetiva, mas da comparação. Com isso, visou atingir junto ao auditório um efeito persuasivo ao afirmar que "as pessoas de preferência heterossexual só podem se realizar ou ser felizes heterossexualmente" e "as de preferência homossexual seguem na mesma toada: só podem se realizar ou ser felizes homossexualmente”. Ao fazer esta comparação, o magistrado apresenta ao auditório uma pesagem na comparação de valores, pessoas e relações que devem ser consideradas iguais e, portanto, devem receber o mesmo tratamento jurídico, tendo em vista terem o mesmo peso e a mesma medida. Dessa maneira, o Ministro-Relator acaba por afastar a concepção assimétrica entre as uniões heteroafetivas e homoafetivas ao lhes dar o mesmo peso e a mesma medida. Assim, por regra de justiça, devem gozar de tratamento igualitário.

Esta estratégia argumentativa utilizada pelo magistrado do STF atribui a seu voto à noção de regra de justiça, para a qual todos aqueles que pertencem a uma nação ou a uma cultura específica, no caso em questão, pessoas em uniões afetivas, sejam elas hetero ou homoafetivas, devem ter os mesmos direitos. Na verdade, estas são formadas por seres humanos e como tais devem ter os mesmos direitos. Ao utilizar a regra de justiça, em sua argumentação, o Ministro-Relator tenta aproximar seu discurso jurídico a nossas ações do dia a dia, do trabalho, de tudo que fazemos. Com isso, estabelece uma clara relação entre regra de justiça e identidade. Como salienta Reboul (1998, p. 170), "Na identidade baseiam-se a regra da justiça: tratar da mesma maneira os seres da mesma 
categoria; o precedente: a admissão de um ato autoriza a cometer atos semelhantes; a reciprocidade: olho por olho".

Assim, numa relação direta com a regra da justiça, temos o argumento da reciprocidade. No caso específico apontado, o Ministro-Relator, ao estabelecer uma simetria entre as uniões hetero e homoafetivas, recorre, a nosso ver, ao princípio da reciprocidade (PERELMAN e OLBRECHTS-TYTECA, 2005). Para tal, faz uso da própria qualificação da situação, tendo em vista a realização ou a instauração da felicidade das pessoas de preferência heteroafetivas com heteroafetivos e as homoafetivas com homoafetivos. Vale salientar a relevância desse argumento como apontam Perelman e Olbrechts-Tyteca (2005, p. 251), "Esses argumentos de reciprocidade [...] parecem [...] ser ao mesmo tempo formais e fundamentados na natureza das coisas. A simetria é suposta o mais das vezes pela própria qualificação das situações”.

É interessante observar que o Ministro-Relator, ao definir o significado do termo jurídico "entidade familiar" atrelado ao reconhecimento da união homoafetiva, que é o cerne da questão das ações do controle concentrado de constitucionalidade ADI 4.277/DF e ADPF 132/RJ, afasta a negatividade que ronda a homossexualidade ou homoafetividade, como defende o Ministro-Relator.

Para tal empreitada, o Ministro-Relator faz uso, em sua argumentação, de elementos que qualificam positivamente a união homoafetiva como estabilidade, a afetividade, a solidariedade e a estrutura espiritual, como se depreende do excerto (3).

(3)

30. Daqui se desata a nítida compreensão de que a família é, por natureza ou no plano dos fatos, vocacionalmente amorosa, parental e protetora dos respectivos membros, constituindo-se, no espaço ideal das mais duradouras, afetivas, solidárias ou espiritualizadas relações humanas de índole privada. O que a credencia como base da sociedade, pois também a sociedade se deseja assim estável, afetiva, solidária e espiritualmente estruturada (não sendo por outra razão que Rui Barbosa definia a família como "a Pátria amplificada"). Que termina sendo o alcance de uma forma superior de vida coletiva, porque especialmente inclinada para o crescimento espiritual dos respectivos integrantes. Integrantes humanos em concreto estado de comunhão de interesses, valores e consciência da partilha de um mesmo destino histórico. Vida em comunidade, portanto, sabido que comunidade vem de "comum unidade". E como toda comunidade, tanto a família como a sociedade civil são usinas de comportamentos assecuratórios da sobrevivência, equilíbrio e evolução do Todo e de cada uma de suas partes. Espécie de locomotiva social 
ou cadinho em que se tempera o próprio caráter dos seus individualizados membros e se chega à serena compreensão de que ali é verdadeiramente o espaço do mais entranhado afeto e desatada cooperação. Afinal, é no regaço da família que desabrocham com muito mais viço as virtudes subjetivas da tolerância, sacrifício e renúncia, adensadas por um tipo de compreensão que certamente esteve presente na proposição spnozista de que, "Nas coisas ditas humanas, não há o que crucificar, ou ridicularizar. Há só o que compreender". (grifos do autor).

A partir dessa qualificação positiva da união homoafetiva, o juiz da Corte Maior utiliza em seu voto a definição de entidade familiar a partir de comparações de pares antagônicos com o intuito de ampliar o significado desse termo jurídico, a fim de abarcar não só a entidade “família tradicional”, mas também a "família homoafetiva”, o que pode ser confirmado no excerto (4).

(4)

II.3. que a terminologia "entidade familiar" não significa algo diferente de "família", pois não há hierarquia ou diferença de qualidade jurídica entre as duas formas de constituição de um novo núcleo doméstico. Estou a dizer: a expressão "entidade familiar" não foi usada para designar um tipo inferior de unidade doméstica, porque apenas a meio caminho da família que se forma pelo casamento civil. Não foi e não é isso, pois inexiste essa figura da sub-família, família de segunda classe ou família "mais ou menos" (relembrando o poema de Chico Xavier). O fraseado apenas foi usado como sinônimo perfeito de família, que é um organismo, um aparelho, uma entidade, embora sem personalidade jurídica. Logo, diferentemente do casamento ou da própria união estável, a família não se define como simples instituto ou figura de direito em sentido meramente objetivo. Essas duas objetivas figuras de direito que são o casamento civil e a união estável é que se distinguem mutuamente, mas o resultado a que chegam é idêntico: uma nova família, ou, se se prefere, Uma nova "entidade familiar", seja a constituída por pares homoafetivos, seja a formada por casais heteroafetivos. Afinal, se a família, como entidade que é, não se inclui no rol das "entidades associativas" (inciso XXI do art. $5^{\circ}$ da CF), nem se constitui em "entidade de classe" (alínea b do inciso XXI do mesmo art. $5^{\circ}$ ), "entidades governamentais" (ainda esse art. $5^{\circ}$, alínea A do inciso LXXII), "entidades sindicais" (alínea c do inciso III do art. 150), "entidades beneficentes de assistência social" ( $\$ 7^{\circ}$ do art. 195), "entidades filantrópicas" ( $1^{-}$do art. 199), ou em nenhuma outra tipologia de entidades a que abundantemente se reporta a nossa Constituição, ela, família, só pode ser uma "entidade ... familiar". Que outra entidade lhe restaria para ser? Em rigor, trata-se da mesma técnica redacional que a nossa Lei das Leis usou, por exemplo, para chamar de "entidades autárquicas" (inciso I do $\S^{\circ}{ }^{\circ}$ do art. 144) as suas "autarquias" ( $\$ 3^{\circ}$ do art. 202). Assim como chamou de "entidade federativa" (§11 do art. 100) cada personalizada unidade política da nossa "Federação" (inciso II do art. 34). E nunca apareceu ninguém, nem certamente vai aparecer, para sustentar a tese de que "entidade autárquica" não é "autarquia", nem "entidade federativa" é algo diferente de "Federação". Por que entidade familiar não é família? E família por inteiro (não pela metade)? 
No excerto (4), notamos que o Ministro-Relator constrói a definição do termo jurídico "entidade familiar" de forma ampla, estabelecendo diversas comparações. Como aponta o Ministro, "entidade familiar" não significa algo diferente de "família". Sendo que a expressão "entidade familiar" não foi usada para designar um tipo inferior de unidade doméstica; inexistência da figura da sub-família, família de segunda classe ou família "mais ou menos"; diferentemente do casamento ou da própria união estável, a família não se define como simples instituto ou figura de direito em sentido meramente objetivo. Na verdade, as figuras de direito que são o casamento civil e a união estável é que se distinguem mutuamente, mas o resultado a que chegam é idêntico: uma nova família; uma nova "entidade familiar", seja a constituída por pares homoafetivos, seja a formada por casais heteroafetivos. Em realidade, a família, como entidade que é, não se inclui no rol das "entidades associativas" (inciso XXI do art. $5^{\circ}$ da CF), nem se constitui em "entidade de classe" (alínea b do inciso XXI do mesmo art. 5º), "entidades governamentais" (ainda esse art. $5^{\circ}$, alínea A do inciso LXXII), "entidades sindicais" (alínea c do inciso III do art. 150), “entidades beneficentes de assistência social” ( $\$ 7^{\circ}$ do art. 195), "entidades filantrópicas" (§1ํำ do art. 199), ou em nenhuma outra tipologia de entidades a que abundantemente se reporta a nossa Constituição. A família só pode ser uma "entidade ... familiar"; uma vez que a "entidade autárquica” não é diferente de “autarquia”, nem “entidade federativa” é algo que se distinga de "Federação”. Então, por que entidade familiar não é família? E família por inteiro (não pela metade).

Desse modo, o Ministro-Relator, a nosso ver, torna eficaz o seu argumento por comparação, na medida em que assegura a comunhão com o auditório, podendo vir a evitar a oposição deste. Ao fazer uso de pares antagônicos para ampliar o conceito de entidade familiar, através da comparação, o Ministro pode ter vindo a gerar o efeito persuasivo pretendido. Este entendimento alargado do sentido atribuído ao termo entidade familiar dado pelo Ministro-Relator talvez tenha sido um dos fatores que contribuiu para a unanimidade do reconhecimento da união homoafetiva como entidade familiar. 


\subsection{Argumentos baseados na estrutura do real}

Os argumentos baseados na estrutura do real são aqueles que se utilizam de "validades" presentes na própria sociedade com o fim de “[...] estabelecer uma solidariedade entre juízos admitidos e outros que se procura promover" (PERELMAN e OLBRECHTS-TYTECA, 2005, p. 298). A partir dessas validades, surgem as ligações de sucessão, que podem ser de vínculo causal, de argumento pragmático, dos fins e dos meios e dos argumentos de desperdício, da direção e da superação, e as ligações de coexistência, que podem ser argumento da pessoa e seus atos, da autoridade, da essência, da ligação simbólica, das hierarquias e das diferenças de grau e ordem.

No entanto, para esta análise, apresentaremos apenas os argumentos pragmáticos (ligação de sucessão) e os argumentos por autoridade (ligação de coexistência) por serem os mais recorrente nos documentos em análise. Dentre os elementos do real associados uns aos outros numa ligação reconhecida, percebemos que a argumentação no voto do Ministro-Relator produz efeitos de sentido argumentativamente orientados, que possibilitam passar daquilo que é admitido ao que se quer admitir.

\section{Argumento pragmático}

A construção da definição do termo jurídico "entidade familiar" de forma ampla pelo Ministro-Relator através do antagonismo anteriormente exposto é feito não somente de argumentos por comparação, mas por argumentos baseados na estrutura do real, uma vez que se utilizam de validades que se apresentam na própria sociedade. Estes, de acordo com Perelman e Olbrechts-Tyteca (2005, p. 298), visam a estabelecer uma solidariedade entre juízos admitidos e outros que se procura promover.

No caso em apreço, o julgador se utiliza, por exemplo, do argumento de que "não há hierarquia ou diferença de qualidade jurídica entre as duas formas de constituição de um novo núcleo doméstico", a fim de estabelecer uma solidariedade com o seu auditório 
de que entre o juízo admitido para "entidade familiar" e "família" não há diferença, pois a terminologia "entidade familiar" não significa algo diferente de "família".

Dessa forma, percebemos que o juiz do STF explora e valoriza as consequências do ato empreendido pela definição dada ao termo jurídico "entidade familiar" de forma a obter a adesão do auditório, dos outros Ministros da Corte Maior Brasileira e do público em geral que assiste ao julgamento pela TVJustiça, assim como dos amici curiae ${ }^{2}$ relativa às ações em questão. Com isso, fortalece a sua tese principal de que a expressão “entidade familiar" é sinônimo de "família”, tanto é que o magistrado afirma que o termo não foi usado para designar um tipo inferior de unidade doméstica, mas como um organismo, um aparelho, uma entidade, embora sem personalidade jurídica, conforme se verifica no excerto (4).

Nesse sentido, podemos afirmar que, ao utilizar argumentos pragmáticos para justificar a tese, o Ministro-Relator se propõe a apresentar a relação de sinonímia perfeita entre "entidade familiar" e "família" com a finalidade de mostrar que a união homoafetiva é uma outra forma de entidade familiar e deve, portanto, ser reconhecida como uma família. O argumento em questão ancora a defesa da tese, demonstrando questões de ordem prática, uma vez que fazem parte do conhecimento do auditório, em virtude do fato de não haver, no entendimento do Ministro-Relator, outro enquadramento para família senão o de "entidade familiar”. O Ministro argumenta, para tal, que a família, como entidade, não se inclui em nenhum do rol de entidades previstas no texto constitucional, como "entidades associativas" (inciso XXI do art. $5^{\mathbf{o}}$ da CF), "entidade de classe" (alínea b do inciso XXI do mesmo art. 5oㅡ), “entidades governamentais" (ainda esse art. 5ํㅜㄹ alínea A do inciso LXXII), “entidades sindicais"

\footnotetext{
${ }^{2}$ A figura do amicus curiae, ou amigo da corte, surgiu no Brasil com a Lei 9.868/99, que dispõe sobre a ação direta de inconstitucionalidade e a ação declaratória de constitucionalidade. Esse instituto jurídico tem a função, grosso modo, de "[...] proporcionar ao juiz condições de proferir decisão mais próxima às reais necessidades das partes e mais rente à realidade do país."(ANTEPROJETO DE CPC/2105), sobretudo nos casos em que há o total desconhecimento pelo julgador da matéria em exame, o que justifica o ingresso de entidades como amici curiae, para esclarecimento dos fatos e do Direito, com a finalidade de ver as causas apreciadas e julgadas corretamente pelo juízo competente. Inclusive, com o advento do Código de Processo Civil de 2015, esse instrumento passou a ser previsto expressamente no artigo 138, cujos pressupostos para sua intervenção decorrem da matéria, da especificidade do tema e objeto da demanda ou da repercussão social da controvérsia.
}

Revista Investigações, Recife, v. 33, No especial, Texto: gêneros, interação e argumentação - III Workshop de Linguística Textual, p. 95 - 121, 2020 ISSN Digital 2175-294x 
(alínea c do inciso III do art. 150), "entidades beneficentes de assistência social" ( $7^{\circ}$ do art. 195), "entidades filantrópicas” (§1ํㅜ do art. 199).

Portanto, o Ministro-Relator mostra que não é novidade para o interlocutor esse entendimento, recorrendo assim ao argumento pragmático de forma a estabeler relações entre os fatos e suas consequências. Considera para tal que a sua argumentação faz uso, em rigor, da mesma técnica redacional que a CRFB de 1988 usou para chamar de "entidades autárquicas" as suas "autarquias". O orador conclui sua fala, indagando que não é possível outro entendimento senão o de compreender a entidade familiar senão como família.

Argumento de autoridade

O argumento de autoridade é conhecido como argumento de prestígio, o qual se utiliza de atos ou de juízos de uma pessoa ou de um grupo de pessoas como meio de prova a formar uma tese, pois o auditório reconhece essa pessoa ou grupo de pessoas como autoridade.

É cediço registrar que Perelman e Olbrechts-Tyteca (2005) chamam a atenção para o fato de que esse argumento, por ter sido muito utilizado, foi bastante criticado nos meios hostis à pesquisa científica, uma vez que, ao ser utilizado de maneira abusiva e indiscriminada, adquiriu status coercitivo, pois se dava a impressão de que as autoridades não podiam ser contestadas.

É interessante observar que essa estratégia argumentativa é bastante recorrente no voto do Ministro-Relator, conforme podemos verificar no excerto (5), como forma de fortalecer a tese assentida por ele. Ao convocar a(s) voz(es) de autoridades reconhecidas, o Ministro-Relator procura legitimar a sua fala.

$(5)$

26. "Bem de todos", portanto, constitucionalmente versado como uma situação jurídica ativa a que se chega pela eliminação do preconceito de sexo. Se se prefere, "bem de todos" enquanto valor objetivamente posto pela Constituição para dar sentido e propósito ainda mais adensados à vida de cada ser humano em particular, com reflexos positivos no equilíbrio da sociedade. O que já nos remete para o preâmbulo da nossa Lei Fundamental, consagrador do 


\begin{abstract}
"Constitucionalismo fraternal" sobre que discorro no capítulo de no VI da obra "Teoria da Constituição", Editora Saraiva, 2003. Tipo de constitucionalismo, esse, o fraternal, que se volta para a integração comunitária das pessoas (não exatamente para a "inclusão social"), a se viabilizar pela imperiosa adoção de políticas públicas afirmativas da fundamental igualdade civil-moral (mais do que simplesmente econômico-social) dos estratos sociais historicamente desfavorecidos e até vilipendiados. Estratos ou segmentos sociais como, por ilustração, o dos negros, o dos índios, o das mulheres, o dos portadores de deficiência física e/ou mental e o daqueles que, mais recentemente, deixaram de ser referidos como "homossexuais" para ser identificados pelo nome de "homoafetivos". Isto de parelha com leis e políticas públicas de cerrado combate ao preconceito, a significar, em última análise, a plena aceitação e subseqüente experimentação do pluralismo sócio-político-cultural. Que é um dos explícitos valores do mesmo preâmbulo da nossa Constituição e um dos fundamentos da República Federativa do Brasil (inciso V do art. 1o). Mais ainda, pluralismo que serve de elemento conceitual da própria democracia material ou de substância, desde que se inclua no conceito da democracia dita substancialista a respeitosa convivência dos contrários. Respeitosa convivência dos contrários que John Rawls interpreta como a superação de relações historicamente servis ou de verticalidade sem causa. Daí conceber um "princípio de diferença", também estudado por Francesco Viola sob o conceito de "similitude" (ver ensaio de Antonio Maria Baggio, sob o título de "A redescoberta da fraternidade na época do 'terceiro' 1789", pp. 7/24 da coletânea "O PRINCÍPIO ESQUECIDO", CIDADE NOVA, São Paulo, 2008).
\end{abstract}

A evocação ao filósofo Joh Rawls, professor de filosofia política na Universidade de Harvard, autor de obras clássicas como, Uma Teoria da Justiça, Liberalismo Político e O Direito dos Povos, citado por Francesco Viola, revela que a tese do Ministro-Relator é fortalecida pela referência às obras citadas. Através desta, o Ministro defende o bem de todos como elemento norteador da Carta Política de 1988 e veda qualquer tipo de discriminação, pois a regra da justiça de Rawls, grosso modo, é de que sociedade deve assegurar ao máximo os direitos básicos (humanos e fundamentais) a todos os indivíduos (princípio da Igual Liberdade) e de que as desigualdades sociais e econômicas devem ser distribuídas de tal forma que garantam os maiores benefícios possíveis aos menos favorecidos (princípio de diferença). Uma vez esses direitos asssegurados a todos, é possível, na esteira do pensamento do filósofo Rawls e como defende o MinistroRelator em seu voto, uma convivência respeitosa e harmoniosa entre os hetero e homoafetivos, através da garantia dos maiores benefícios possíveis aos homoafetivos, que representam os menos favorecidos, por meio do reconhecimento da união homoafetiva como entidade familiar, conforme se extrai no excerto (4). 
Consequentemente, o reconhecimento da união homoafetiva como entidade familiar constitui um atendimento ao instituto constitucional do bem de todos.

\subsection{Argumentos que fundamentam a estrutura do real}

Os argumentos que fundamentam a estrutura do real podem ser de dois tipos. Aqueles que se baseiam na apresentação de um caso particular, como o argumento por exemplo, argumento por ilustração e argumento por modelo/antimodelo e aqueles que se centram na relação entre as estruturas, como a analogia e a metáfora. Centrar-nosemos aqui no argumento pela metáfora.

\section{Argumento pela metáfora}

O argumento pela metáfora ou apenas metáfora é um argumento derivado da analogia, cujo funcionamento consiste em expressar elementos do tema e do foro como omissão de outros com o objetivo, dentro do processo argumentativo, de proporcionar a assimilação do domínio do tema ao do foro, para criar uma emoção poética, mesmo o texto não sendo poético.

No excerto (6) retirado do voto do Ministro-Relator, percebemos que o julgador faz uso da metáfora destacada na sua argumentação logo no início do seu voto.

(6)

4. Seja como for, o fato é que me foi redistribuída a ADI no 4.277, versando o mesmo tema central da ADPF no 132. Dando-se, por efeito mesmo dessa distribuição, uma convergência de objetos que me leva a subsumir ao mais amplo regime jurídico da ADI os pedidos insertos na ADPF, até porque nela mesma, ADPF, se contém o pleito subsidiário do seu recebimento como ADI. Por igual, entendo francamente encampados pela ADI no 4.277 os fundamentos da ADPF em tela (a de no 132-DF). Fundamentos de que se fez uso tanto para a pretendida "interpretação conforme" dos incisos II e V do art. 19 e do art. 33 do Decreto-Lei no 220/1975 (Estatuto dos Servidores Públicos Civis do Estado do Rio de Janeiro) quanto para o art. 1.723 do Código Civil brasileiro, assim vernacularmente posto: "É reconhecida como entidade familiar a união estável entre o homem e a mulher, configurada na convivência pública, contínua e 
duradoura e estabelecida com o objetivo de constituição de família”. É o que me basta para converter a ADPF em ADI e, nessa condição, recebê-la em par com a ADI no 4.277, a mim distribuída por prevenção. Com o que este Plenário terá bem 4 mais abrangentes possibilidades de, pela primeira vez no curso de sua longa história, apreciar o mérito dessa tão recorrente quanto intrinsecamente relevante controvérsia em torno da união estável entre pessoas do mesmo sexo, com todos os seus consectários jurídicos. Em suma, estamos a lidar com um tipo de dissenso judicial que reflete o fato histórico de que nada incomoda mais as pessoas do que a preferência sexual alheia, quando tal preferência já não corresponde ao padrão social da heterossexualidade. $E$ a velha postura de reação conservadora aos que, nos insondáveis domínios do afeto, soltam por inteiro as amarras desse navio chamado coração. (grifo nosso)

O Ministro-Relator, com o uso da metáfora "nos insondáveis domínios do afeto, soltam por inteiro as amarras desse navio chamado coração", marca, de acordo com Gomes (2017), um elemento passional persuasivo. A inserção deste elemento tem o objetivo de fazer com que o auditório modifique o seu modo de ver e de sentir o julgamento das ações do controle de constitucionalidade sobre o reconhecimento da união homoafetiva como entidade familiar para além da racionalidade da lógicamatemática. Na verdade, para o julgamento de uma demanda com esta temática, é preciso que os julgadores se apropriem de um raciocínio profundo, sem prédeterminações, inexplorado, ou seja, ao nível do "insondável”.

Além disso, o Ministro revela uma interdiscursividade com a máxima de que o “coração tem razões que a própria razão desconhece" e uma intertextualidade com a música Aos pés da Cruz, em que o cantor e compositor João Gilberto faz uso desta máxima. As escolhas linguísticas realizadas pelo orador revelam, como assinalou Gomes (2017), um convite ao auditório para a racionalidade, mas com sensibilidade, ou seja, uma racionalidade sensível, a nosso ver. Tanto é que a expressão "soltam por inteiro as amarras" revela uma interdiscursividade com o ato de soltar o navio para permitir que ele siga até o seu destino, remetendo, como demonstrou Gomes (2017, p. 136):

[...] à liberdade que o juiz deve ter ao julgar uma ação e, o coração metaforizado como navio indica que o afeto, sentimento que brota do coração, [que] permite ao ser humano flutuar, viajar, sonhar e não consegue ser totalmente controlado, segurado, dominado. O coração está livre de amarras (preconceitos), portanto pode amar e ser feliz com a pessoa que escolher, mesmo que seja do mesmo sexo.

Revista Investigações, Recife, v. 33, Nº especial, Texto: gêneros, interação e argumentação - III Workshop de Linguística Textual, p. 95 - 121, 2020 ISSN Digital 2175-294x 
O uso da metáfora neste excerto (6) atesta que esta ultrapassa o sentido tradicional de figura de linguagem, típica dos textos poéticos, na medida em que atua, no caso, como argumento que fundamenta a estrutura do real. A sua função é a de persuadir o auditório para tornar o discurso jurídico-poético coerente com a afetividade que o caso do reconhecimento da união homoafetiva como entidade familiar requer.

\subsection{Construção ethos e pathos do ministro-relator no julgamento da ADPF no 132/RJ e da ADI no $4.277 / D F$}

Ao longo de todo o Voto, o Ministro-Relator da ADPF nº 132/RJ e da ADI no 4.277/DF faz uso da $1^{\underline{a}}$ pessoa do singular, como podemos ver em alguns trechos que seguem e que foram retirados do Voto em análise no excerto (7):

(7)

"Começo este voto pelo exame do primeiro pedido do autor da ADPF ㄲo ${ }^{132-}$ RJ, consistente na aplicação da técnica da "interpretação conforme a Constituição" aos incisos II e V do art. 19, mais o art. 33, todos do DecretoLei no 220/1975 [...]" (§ıํㅡ) (grifamos); "Precisamente como, em parte, faz a

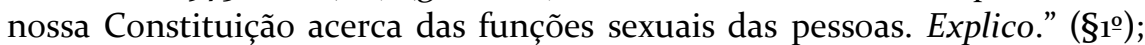
"Faço uma primeira síntese, a título de fundamentação de mérito do presente voto." (\$2 $\left.5^{\circ}\right)$; "Por último, anoto que a Constituição Federal remete à lei a incumbência de dispor sobre a assistência do Poder Público à adoção [...]" (\$36o); "Dando por suficiente a presente análise da Constituição, julgo, em caráter preliminar [...]”(§37º) (grifos nossos).

Esse uso da $1^{\underline{a}}$ pessoa no Voto em análise mostra claramente o desejo de o Ministro-Relator criar nos enunciatários a evidência empírica: a sequência linear dos eventos e a tentativa de presença do enunciador que se aproxima do enunciado constituindo, dentre outros, alguns dos fatores responsáveis pela ilusão de uma reprodução subjetiva e parcial da sua decisão diante da temática controversa no

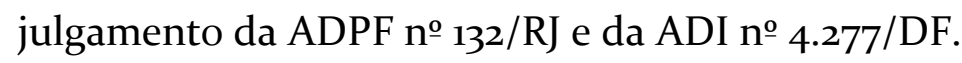

A construção pessoal é, pois, uma estratégia argumentativa de pessoalização de assumir o agente humano (o autor), no caso o Ministro-Relator da ADPF no 132/RJ e da 
ADI no 4.277/DF, a responsabilidade pela decisão proferida em seu Voto, sendo os dados factuais apenas um dos elementos argumentativos balizadores da sua decisão, até porque "sob a perspectiva do discurso, os enunciadores devem assumir o seu dizer e o seu pensar, a partir de suas experiências pessoais, representações, ideologias, convenções de toda ordem.” (CORACINI, 2007, p. 175).

Além disso, o uso da $\mathbf{1}^{\mathrm{a}}$ pessoa, marca a voz do Relator em seu Voto. Este revela, para os outros Ministros do STF, seu compromisso com as informações apresentadas, já que regimentalmente é o responsável por fazer um estudo aprofundado da temática a ser decidida e, ainda, o seu grau de envolvimento com a temática. Isso demostra que o discurso jurídico do Ministro-Relator acaba por apresentar um tom subjetivo, opinando, orientando e julgando sobre o reconhecimento da união homoafetiva como entidade familiar. É um ethos comprometido e engajado que se constrói, fiel aos preceitos constitucionais.

Observamos, ainda, a seleção de expressões como "exatamente" (modalidade epistêmica), durante a construção da argumentação sobre oposicionamento do mérito da causa, ou seja, o reconhecimento da união homoafetiva como entidade familiar, como se verifica no excerto (8) §10o do Voto em questão:

(8)

"O artigo, versante sobre os "objetivos fundamentais" da nossa República Federativa; o inciso, a incorporar a palavra 'sexo' para emprestar a ela o nítido significado de conformação anátomo-fisiológica descoincidente entre o homem e a mulher. Exatamente como se verifica nas três outras vezes em que o mesmo termo é constitucionalmente usado (inciso XLVIII do art. $5^{\circ}$, inciso XXX do art. $7^{\mathbf{o}}$ e inciso II do $\S 7^{\circ}$ do art. 201)." (grifos do Relator do Voto).

Essa unidade textual (PINTO, 2010) funciona como comentário do locutor, Ministro-Relator, a respeito da presença da palavra "sexo" no texto constitucional, o que revela um significado que não comporta o significado apenas referente a homem e a mulher, colaborando com o posicionamento favorável ao reconhecimento da união homoafetiva como entidade familiar.

Outro elemento interessante é a escolha e a justificativa pelo termo "homoafetividade", o que revela, em nosso entendimento, uma marca de 
posicionamento avaliativo do Ministro-Relator, diante da visão favorável do reconhecimento da união homoafetiva como entidade familiar. Na verdade, existe uma mudança de foco na discussão: da ideia de sexo para o da afetividade, norteador atual do Direito de Famílias (DIAS, 2005). Tal seleção mostra o posicionamento assumido pelo Ministro em seu Voto, fazendo com que os interlocutores, através da interpretação dos princípios juridícos atrelados ao Direito de Família sob o prisma constitucional, também se posicionem a favor da perspectiva por ele defendida.

Ainda a utilização de expressões avaliativas contribui para a construção do seu posicionamento crítico-argumentativo quanto ao reconhecimento da união homoafetividade como entidade familiar.

As expressões entre aspas, como o “homem” e “mulher” (§35), “família” (\$33 e §35), uma canhestra liberdade “mais ou menos" (\$34), "entidade familiar” (\$35), família de segunda classe ou família "mais ou menos" (\$35), dentre outras, revelam a construção de uma imagem progressista e inovadora do Ministro-Relator, perante seus pares. Com isso, ele reflete, em certa medida, um posicionamento oposicionista aos Ministros com pensamentos retrógrados e conservadores diante do tema central da ADPF no 132/RJ e da ADI no 4.277/DF.

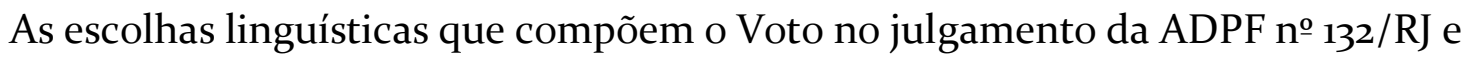
da $\mathrm{ADI}$ no 4.277/DF não são realizadas aleatoriamente, mas refletem o posicionamento dele em relação aos fatos apresentados no Voto em questão. Vale salientar que essas escolhas são influenciadas tanto por componentes externos quanto internos (PINTO, 2010) 3 ao próprio Voto. Destas, podemos depreender várias imagens do Ministro ao longo do texto e, consequentemente, vários ethè são construídos: o autoritário, o analista, o crítico e até mesmo poético.

A construção de imagens de si do Ministro procura explicitar o posicionamento ideológico defendido por ele em seu Voto. A partir das imagens do locutor explicitadas, temos, nos primeiros parágrafos do Voto em análise, um locutor preocupado em expor as preliminares e analisá-las, trazendo com essa imagem o ethos de Analista e, em certa

\footnotetext{
${ }^{3}$ Para maiores detalhes sobre os componentes externos e internos de uma argumentação em gêneros, recomendamos a leitura na íntegra da obra de Pinto (2010), pois, considerando a densidade da proposta da autora, não caberia descrevê-la no espaço deste artigo.
} 
medida, o ethos Autoritário e propondo ao seu leitor um pathos racional. Quando da leitura do Voto, este, através de movimentos inferenciais, consegue chegar a conclusões lógicas e jurídicas compatíveis com o ordenamento da legislação pertinente ao caso. Referimo-nos sobretudo ao exposto na Lei n $1^{\circ}$ 9.882/1999, que dispõe sobre o processo e julgamento da Arguição de Descumprimento de Preceito Fundamental (ADPF), nos termos do $§ 1^{\circ}$ do art. 102 da Constituição da República Federativa do Brasil (CRFB).

Na medida em que admite e usa o vocábulo "homoafetividade", termo cunhado por Dias (2005), e outras expressões entre aspas, presente no voto em análise, o MinistroRelator revela um ethos progressista e inovador perante seus pares. Inclusive, de certa medida, reflete um posicionamento oposicionista aos éthe retrógrados e conservadores de outros Ministros da Corte Maior diante do reconhecimento da união homoafetiva como entidade familiar. Nesse caso, o pathos é chamado a proceder uma leitura crítica, pois este tem a capacidade de se revoltar com o posicionamento apresentado, caso tenha visão diferente do Ministro-Relator, expressando, por meio do contradiscurso, um posicionamento favorável ou contrário à sua posição.

\section{Conclusão}

Através deste trabalho, demonstramos a relevância das técnicas argumentativas para a construção do ponto de vista do Ministro Relator do STF, Carlos Ayres Britto, relativo à ação de descumprimento de preceito fundamental (ADPF) $\mathrm{n}^{\circ}$. 132/RJ e à ação direta de inconstitucionalidade (ADI) $\mathrm{n}^{\circ} .4277 / \mathrm{DF}$, no que tange à união homoafetiva.

Com o levantamento dos argumentos quase lógicos (contradição e comparação), os baseados na estrutura do real (pragmáticos e por analogia), os que fundamentam a estrutura do real (metáfora) e os diversos elementos linguísticos que os compõem foram ressaltados os diversos ethè do Relator, entre ele, destacamos: um ethos progressista e inovador, analista e autoritário, mas também poético e, por estar assente em princípios constitucionais, também patriótico. Na verdade, esses diversos ethè são convocados para 
atingir um pathos que tem de ser convencido de diversas formas para a desconstrução de valores retrógrados construídos socialmente e impostos durante décadas.

\section{Referências}

AMOSSY, Ruth. Apologia da polêmica. Coordenação da tradução Mônica Magalhães Cavalcante; Trad. Rosalice Botelho Wakim Souza Pinto et al. São Paulo: Contexto, 2017. AMOSSY, Ruth. Argumentação no discurso. Trad. (coord.) Eduardo Lopes Piris e Moisés Olímpio Ferreira. São Paulo: Contexto, 2018.

ANSCOMBRE, J.-C; DUCROT, O. L 'Argumentation dans la langue. Liège: Mardaga, 1988. BRASIL. Constituição (1988). Constituição da República Federativa do Brasil. Brasília: Senado Federal, Centro Gráfico, 1998.

BRASIL. Lei no. 10.416, de 10 jan. 2002. Código Civil Brasileiro. Diário Oficial da União, Brasília, 11 jan. 2002. Brasília: Senado Federal, Centro Gráfico, 2002.

BRASIL. Lei nº. 9.882, de 03 dez. 1999. Dispõe sobre o processo e julgamento da arguição de descumprimento de preceito fundamental, nos termos do $\S 10$ do art. 102 da Constituição Federal. Diário Oficial da União, Brasília, o6 de dezembro de 1999. Brasília: Senado Federal, Centro Gráfico, 1999.

BRASIL. Supremo Tribunal Federal. Processo: ADI 4.277/DF. Relator: Ministro Ayres Britto. Órgão julgador: Tribunal Pleno. Data do julgamento: 05 maio 2011. Diário de Justiça eletrônico, 198, 14 out. 2011. Disponível em: <http://stf.jusbrasil.com.br/jurisprudencia/20627236/acao-direta-deinconstitucionalidade-adi-4277-df-stf \&gt; >. Acesso em: 15 ago. 2013.

BRASIL. Supremo Tribunal Federal. Processo: ADPF 132/RJ. Relator: Ministro Ayres Britto. Órgão julgador: Tribunal Pleno. Data do julgamento: 05 maio 2011. Diário de Justiça eletrônico, 198, 14 out. 2011. Disponível em: <http://www.stf.jus.br/portal/geral/verPdfPaginado.asp?id=433816\&amp;tipo=TP\&amp ;descricao=ADPF\%2F132\&gt; >. Acesso em: 15 ago. 2013.

CORACINI, Maria José Rodrigues Faria. Um fazer persuasivo: o discurso subjetivo da ciência. 2. ed. Campinas (SP): Pontes, 2007. 
DIAS, Maria Berenice. União homossexual, o preconceito e a justiça. 3. ed. Porto Alegre: Livraria do Advogado, 2005.

FIORIN, José Luiz. Argumentação. São Paulo: Contexto, 2015.

GOMES, Acir de Matos. O judiciário e a retórica sexista: valores, hierarquia e lugares retóricos. 208 f. 2017. Tese (Doutorado em Língua Portuguesa) - Pontifícia Universidade Católica de São Paulo, São Paulo, 2017.

MACEDO, Patrícia Souza Almeida de. Análise da argumentação no discurso. 242 f. 2018. Tese (Doutorado em Linguística) - Universidade Federal do Ceará, Departamento de Letras Vernáculas, Programa de Pós-graduação em Linguística, Fortaleza (CE), 2018. OLIVIER, Reboul. Introdução à Retórica. Trad. Ivone Castilho Benedetti. São Paulo: Martins Fonte, 1998.

PERELMAN, C.; OLBRECHTS-TYTECA. Tratado da argumentação: a nova retórica. Trad. Maria Ermantina de Almeida Prado Galvão; Revisão da tradução Eduardo Brandão. 2⿳⺈冂= edição. São Paulo: Martins Fontes, 2005.

PINTO, Rosalice. Como argumentar e persuadir? Práticas: política, jurídica e jornalística. Lisboa: Quid Juris Sociedade Editora, 2010.

PISTORI, Maria Helena Cruz. Ethos e pathos no discurso do Ministro-Relator do Supremo Tribunal Federal, Baktiniana, São Paulo, v. 13, n. 1, p. 71-93, jan. Abril, 2018.

PLANTIN, Cristophe. Essais sur l'argumentation. Paris: Kimé, 1990.

SILVA, De Plácido E. Vocabulário jurídico. 12. ed. Rio de Janeiro: Forense, 1997.

TODOROV, Tzvetan. Os gêneros do discurso. Tradução Ana M. Leite. Lisboa : Edições $70,1981$.

Recebido em 10/03/2020.

Aprovado em 31/05/2020. 